\title{
Innovative Logistics as a Competitive Market Force
}

\author{
Natalia Petrovna Karpova ${ }^{1}$ \\ Irina Anatolievna Toimenceva² \\ 1. Samara State University of Economics, Russia, 443090, Samara, Sovetskoi Armii Street, 141 \\ 2. Samara State University of Economics, Russia, 443090, Samara, Sovetskoi Armii Street, 141 \\ Correspondence: Samara State University of Economics, Samara 443090, Russia, 141 Sovetskoi Armii St
}

\section{Doi:10.5901/mjss.2015.v6n6s3p496}

\section{Abstract}

In modern economy the logistics becomes an important factor of organizations competitiveness increase. The logistics possesses innovative potential in management sphere, capable to increase managing efficiency of market subjects, and it defined the relevance of research. A research objective is theory and methodology development of market analysis that allowed to prove and expand competition model by means of innovative logistics as independent competitive force that in conditions of scientific and technical progress and quickly changing market helps the companies to give a comprehensive assessment to the competition and to keep leadership in the process of objectives achievement and strategy realization.

Keywords: logistics, basic logistics, innovative logistics, market, competitive forces, innovation, innovative activity, innovative activity, administrative innovation.

\section{Introduction}

In modern conditions strategic planning becomes an actual direction of logistic systems development allowing to identify companies efficiency sources to form and put into practice the strategy focused on long-term competitive advantages creation. In turn, the logistics, in particular innovative logistics, forms sources of organizations efficiency. Application of innovative logistics principles and methods in companies activity is a strategic reference point in taking a competitive position on the market.

Using logistics methods the principle of freedom in a choice of partners allows organizations to save expenses significantly due to optimization of interconnected logistics fields (supply, production and distributions) which have a great influence on enterprise economy, defining its viability. Logistics, acting as a system integrator of physical advance processes of goods and services, provides the clearness of logistic processes, latest management tools application and decrease in cumulative expenses in deliveries chains that is a necessary condition to keep a leading position on the market. The logistics sets strategic reference points to which companies should try to achieve within corporate strategy purposes realization.

The powerful contribution to development of strategic planning issues and market research was brought by such scientists as Aaker (2007), Ansoff (2009), Mintsberg (2001), Porter (2005; 2006), Thompson and Strickland (2006), Faye and Rendell (2002), Kaplan and Norton (2006), Sergeyev (2005), Fatkhutdinov (2008), etc.

Works of Dybskaya's (2009), Kurbatova (2007; 2008), Novikova (2007; 2009), Sergeyev (2005; 2009), Lukinsky (2007), Bauersocks and Kloss (2008), Linders and Fearon (2006), Stock and Lambert (2005), Waters (2003) are devoted to logistics issues studying including innovative logistics.

Scientific elaborations of these scientists made a huge contribution to the development of strategic planning in logistics in theory and practice, but debatability of markets analysis issues specified a research subject within strategy development

\section{Research Methods}

Many scientists understand strategic planning companies strategy formation issues in different ways.

So, strategic planning, according to D Aaker (Aaker, 2007), is concentrated on a market environment in which the company carries out its activity. Thus, the attention is paid not only to forecasting, but also profound market studying, in particular competitors activity research and buyers needs. Thereby the company hopes to study present situation, and 
also to foresee changes which can have strategic consequences.

G. Mintsberg denies a strategy concept as a plan which is formed at first in developer's head. He considers a strategy as set of different activity types which are carried out during certain time which include also supervision over the events happening inside and outside the company. G. Mintsberg does not insist on uselessness of planning, he only says that actions more important, than intentions. His idea about it, in our opinion, remains disputable. (Mintsberg, 2001: 533538)

M. Porter sees the purpose of strategic planning in research of each competition component, assessment of major factors importance and presenting a full picture of market capacity. (Porter 2005; 2006)

According to M.R. Linders, H.E. Fearon, strategy is an action plan, intended for achievement of company specific long-term goals. Strategy has to be concentrated on key factors necessary for success, and main actions which need to be undertaken now to achieve future results. Thus, strategy is a process of company interaction with environment, longterm goals defining and business purposes achievement by means of productive and effective resources placement. (Linders and Fearon, 2006: 720)

R. S. Kaplan, D.P. Norpo tone consider strategy in a form of certain hypotheses about causes and effects from the point of view of consumer choice and market segments where the company intends to work, defining those critical internal business processes which should be perfected to make valuable suggestions for target consumer, and selecting individual and organizational opportunities is necessary for internal, client and financial purposes achievement. Such approach completely corresponds to M. Porter's works according to corporate strategy. (Kaplan and Norton, 2006: 33-40)

According to A.A. Thompson, A. J. Strickland, strategy represents the comprehensive management plan which strengthens company position on the market and provides efforts coordination, consumers attraction and satisfaction, successful competition and global purposes achievement. In other words, strategy is a competition methods combination and business organization directed on clients satisfaction and organizational purposes achievement. Process of strategy elaboration is based on careful studying of all possible development directions and represent itself a choice of general direction, mastered markets, served requirements, competition methods, attracted resources and business models. According to scientists opinion, the concept of business model (business model) is closely connected with strategy concept implying a way of receiving profit from company activity. (Thompson and Strickland, 2006)

Speaking about logistics, it should be noted that in Russia it is rather young science. In scientific literature there were two directions in logistics definition: one is connected with functional approach to merchandising, another reflects administrative aspect of logistics (tab. 1).

Table 1. Standard logistics definitions

\begin{tabular}{|c|c|c|c|}
\hline & Logistics as science & $\begin{array}{l}\text { Logistics as a concept of object } \\
\text { management }\end{array}$ & Logistics as process \\
\hline 1 & 2 & 3 & 4 \\
\hline $\begin{array}{l}\text { Functional aspect of } \\
\text { logistics }\end{array}$ & $\begin{array}{l}\text { Logistics - science about planning, control and } \\
\text { transportation management, warehousing and other } \\
\text { material and non-material operations made in the } \\
\text { course of bringing raw materials and materials to } \\
\text { manufacturing installation, intra factory raw materials } \\
\text { processing, materials and semi-finished products, } \\
\text { bringing finished product to a consumer according to } \\
\text { his interests and requirements, and also relevant } \\
\text { information transferring, storage and processing } \\
\end{array}$ & $\begin{array}{l}\text { Logistics is a forecasting concept based } \\
\text { on high reliability level achievement of } \\
\text { delivery processes management and } \\
\text { therefore this concept implementation } \\
\text { provides to businessmen relative } \\
\text { stability of their activity in the conditions } \\
\text { of market environment uncertainty. }\end{array}$ & $\begin{array}{l}\text { Logistics is a process of expenses planning, } \\
\text { realization and control, materials movements } \\
\text { and storages, semi-finished products and } \\
\text { finished product, and also related information } \\
\text { on goods delivery from production place to a } \\
\text { consumption place according to client } \\
\text { requirements. }\end{array}$ \\
\hline $\begin{array}{l}\text { Managerial aspect of } \\
\text { logistics }\end{array}$ & $\begin{array}{l}\text { Logistics is a science about concentration processes } \\
\text { management, material distribution and movement, } \\
\text { service, information and financial streams and these } \\
\text { streams parameters optimization in micro or } \\
\text { macroeconomic system to achieve stated objects. }\end{array}$ & $\begin{array}{l}\text { Logistics is a concept of enterprises } \\
\text { management, organizations and their } \\
\text { associations based on rational systems } \\
\text { application of resources production } \\
\text { concentration / distribution and bringing } \\
\text { finished product and services to an end } \\
\text { consumer according to his interests }\end{array}$ & $\begin{array}{l}\text { Logistics is process of production } \\
\text { management, materials movement and } \\
\text { storage, products and goods, and also } \\
\text { information streams accompanying them by } \\
\text { means of merchandising channels organization } \\
\text { so current and future expenses are minimized } \\
\text { on condition of highly effective (reliable) orders } \\
\text { completion and delivery. }\end{array}$ \\
\hline
\end{tabular}

Thus, theoretical, methodological and information research base are scientific works of domestic and foreign scientists in the field of logistics, strategic planning, management, system analysis; special, instructive, methodical and scientific and technical literature. Conceptual provisions and conclusions of research are based on the principles of systemacity and adaptability. A methodological research basis is a set of general scientific and special methods of scientific perception. 


\section{Results}

In scientific literature there were two directions in logistics definition: one is connected with functional approach to merchandising, another reflects managerial aspect of logistics.

In turn, many scientists divide logistics into two main types: basic and innovative. Basic logistics represents real-life in a certain period and also organized forms, methods and algorithms of stream management processes which are rather steady in this time period and they make logistics fundamentals as an activity field and science.

Innovative logistics is an actual component of logistics science and activity field corresponding to it which is urged to study necessity and possibility of progressive innovations introduction in organization of current and strategic stream management processes in economic and other public structures to identify and use additional resourses by this management rationalization (optimization). (Kurbatov, 2007; Novikov, 2009). Thus, innovative logistics can be considered as an management innovation. The most important component of innovative logistics is strategic which represents science and practice of logistic potential accumulation of various stream management processes systems by long-term programs development of innovative transformations within planned paradigm of their strategic development.

Strategic logistics gives the chance to develop constructive strategic development program of the company aimed at optimum organization of stream processes and long-term success on the market, which was determined by structurally functional (process) content of the company. It means that not only the structure of intra firm divisions, but also company mission become derivatives of strategic logistics solutions in its integration alternative in the future. Thus, according to scientists, modern economic development nature assumes the solution of all complex of interconnected tactical and strategic management tasks in required time mode on the basis of logistic system capacity use for goals achievement. The logistics in modern conditions becomes one of the most important components of strategic development of this or that structure and depends not only on paradigm definition of such development, but also substantially influences this choice.

Basis of company strategy development, according to M. Porter (Porter, 2006), is companies adaptation to the competitive environment in which following main forces confront: suppliers, consumers, goods substitutes, new market participants and competitors. Influence of these forces on company position on the market is possible to represent schematically (fig. 1).



1. Forces managing competition in branch (Porter, 2005: 45)

There is also other point of view determining competitive forces on the market reflected in L. Faey and R. Rendell's work. It is a model of pure (total) value. 


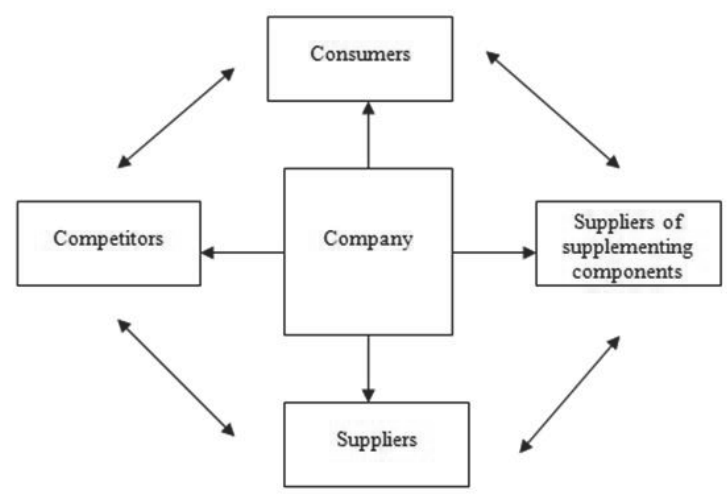

Figure 2. Model of pure value (Faey and Rendell, 2002: 278)

Model of pure value shows the important role played by suppliers of supplementing components which represent the sixth competitive force on the market i.e. by people or structures at which consumers buy additional goods or services or to whom suppliers sell additional initial components, they influence business success or failure significantly. The role of such suppliers specularly reflects rivals position (including new participants, goods substitutes and acting competitors). From the point of view of demand they increase buyers desire to pay for certain production. From the point of view of suggestion they reduce the price required by suppliers for initial components. According to scientists, suppliers of supplementing components meet in many business fields. But they are especially important when business types create absolutely new ways of some actions implementation or there to combine various systems types which separately work well, there are necessary standards allowing to coordinate them with each other.

According to scientists big benefit from serious approach to suppliers of supplementing components is shown that it adds a cooperation coordinate to competitive forces model of M. Porter. In this context scientists give an example which opens an essence of this coordinate: The Windows operating system of Microsoft corporation works more effectively at computers with Pentium microprocessor of Intel company. But even in these conditions Microsoft and Intel can not consider each other if they work on model basis of M. Porter. However common sense makes us assume that these companies have to treat each other as important market participants (Porter, 2005).

In our opinion, suppliers division into two components and their allocation in two different competitive forces is inexpedient, as all suppliers can threat competitive fight and influence interaction strategy definition including strategic partners presented in this model as suppliers of supplementing components.

Thus, our point of view favors the model of five forces offered by M. Porter. Thus, in our opinion, a competition model presented to scientists could be added with the innovations which are an important competitive force in modern economy and they create barriers to enter the market.

Companies innovative activity is possible to present in a form of actions system for scientific and intellectual potential use to receive new or improved goods and services, their production ways to increase competitiveness and enterprise market positions strengthening.

According to R. A. Fatkhutdinov, innovation is a resulting effect of novelty introduction to change management object and to receive economic, social, ecological, scientific and technical or other effect. (Fatkhutdinov, 2008).

T.A. Ilyina defines innovation as result of ideas, researches, development transformation in a new, improved or changed scientific and technical or social and economic decision, which purpose to find economic content and to be demanded in society (llyina, 2006). Innovations are attracted in production actively only when demand increase requires sharp increase in output, i.e. to implement innovative activity economic conditions are priority. Thus economic effect takes often economic subject who did not necessarily create an innovation, but applied it. This hypothesis, according to T.A. Ilyina, coordinates economy innovative opportunities growth with market requirements, new branches emergence and old brunches reconstruction. Driving force of modern innovative economy is competition based on new goods launching, as well as new technology inventing, a new raw materials source finding, new organization type setting up. This competition provides resolute expenses reduction or quality improvement, drives companies out of the market which did not follow a way of innovative updating. Goods and services producer has to feel in a competitive situation even then when he is a monopolist as the competition on innovations basis creates potential threat to business, starts the process of creative 
destruction in economy. Thus, a driving force of modern market is innovations acting as the result of companies innovative activity owing to their innovative activity. Innovations introduction has impact on market opportunities of the companies. Thus innovations can keep or destroy these opportunities. Therefore, in competitive fight that company wins which uses innovations in commercial activity, creating additional barriers for competitors to enter the market. Summing up the result, it is possible to present forces managing competition on the market (fig. 3).

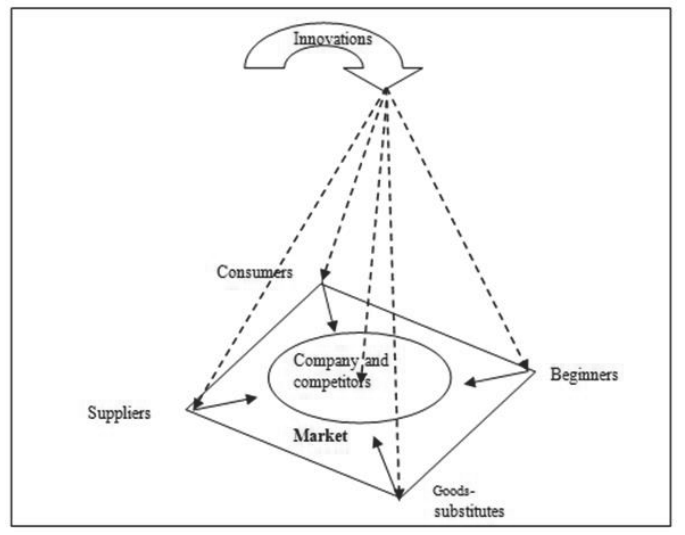

Figure 3. Forces managing competition on the market

From a presented figure 3, as a result of market subjects innovative activity, suppliers innovative activity of consumers, potential competitors, goods substitutes producers intensifies and it reflects in new competitive force emergence on innovations market. So the innovations used by competitors are reflected on the market stronger, and, therefore, they are the most dangerous. Thus, in conditions of scientific and technical progress and quickly changing market it is possible to keep leadership on the market only in case innovations application in enterprise activity. All market subjects can apply innovative development: existing or potential competitors, suppliers or consumers. Owing to novelty goods suggestion to the market by main or potential competitor, an enterprise can miss potential consumers, profit, and as a result to lose in competitive fight. At innovations introduction to enterprises suppliers or consumers it is possible to feel pressure from their part.

Therefore it is necessary to monitor grocery, technological and important, competitors management innovations of (existing and potential), suppliers and consumers.

Competitive forces, barriers and risk factors which take part in enterprise strategy formation, are considered in table 2.

Table 2. Competitive forces and risk factors at enterprise strategy formation.

\begin{tabular}{|c|c|c|c|}
\hline № $\Pi / \Pi$ & Competitive forces & Risk factors and barriers to enter on the market & Strategic actions \\
\hline 1 & 2 & 3 & 4 \\
\hline \multirow{6}{*}{1} & \multirow[t]{6}{*}{ Beginners } & Economy on the scale & \multirow{6}{*}{$\begin{array}{l}\text { Vertical integration } \\
\text { Growth of output, market research, field service. } \\
\text { Complex of advancement application } \\
\text { Advanced technologies application, governmental } \\
\text { subsidies. } \\
\text { Economic communications establishment with suppliers } \\
\text { and consumers (sales channels expansion) }\end{array}$} \\
\hline & & Differentiation of goods and services & \\
\hline & & Need for capital investments & \\
\hline & & High constant expenses & \\
\hline & & Access to long-standing distribution channels & \\
\hline & & Public policy & \\
\hline \multirow{4}{*}{2} & \multirow[t]{4}{*}{ Suppliers } & $\begin{array}{l}\text { Goods and services differentiation (uniqueness), } \\
\text { lack of goods substitutes }\end{array}$ & \multirow[t]{4}{*}{$\begin{array}{l}\text { Suppliers market analysis of inventory items } \\
\text { Establishment of partnership with key suppliers }\end{array}$} \\
\hline & & $\begin{array}{l}\text { A small amount of suppliers in a certain market } \\
\text { segment }\end{array}$ & \\
\hline & & $\begin{array}{l}\text { Integration threat of } \\
\text { consumer business }\end{array}$ & \\
\hline & & Consumers are not a key segment for suppliers & \\
\hline 3 & Consumers & Consumers concentration, purchases & Segmentation of consumers market \\
\hline
\end{tabular}




\begin{tabular}{|c|c|c|c|}
\hline & & implementation in large volumes & \multirow{6}{*}{$\begin{array}{l}\text { Level increase of consumers maintenance service } \\
\text { Advance complex application (advertizing, stimulation of } \\
\text { sales, etc.) } \\
\text { Goods and services quality improvement } \\
\text { Decrease in goods and services prime cost } \\
\text { Labor productivity increase }\end{array}$} \\
\hline & & $\begin{array}{l}\text { Commonality of acquired goods, existence of } \\
\text { goods substitutes }\end{array}$ & \\
\hline & & $\begin{array}{l}\text { Suppliers goods and services are a component of } \\
\text { consumers products (price plays a crucial role) }\end{array}$ & \\
\hline & & $\begin{array}{l}\text { Suppliers goods and services influence quality of } \\
\text { consumers products }\end{array}$ & \\
\hline & & $\begin{array}{l}\text { Supplier goods and services do not save } \\
\text { consumer means (quality plays a major role) }\end{array}$ & \\
\hline & & Threat of integration into supplier business & \\
\hline \multirow[b]{2}{*}{4} & \multirow[t]{2}{*}{ Goods (services) - substitutes } & Ability to the best ratio of price and quality & \multirow{2}{*}{$\begin{array}{l}\text { Advance complex application } \\
\text { Quality improvement of goods and services } \\
\text { Differentiation of goods and services }\end{array}$} \\
\hline & & Production in a profitable market segment & \\
\hline \multirow{5}{*}{5} & \multirow[t]{5}{*}{ Competitors } & $\begin{array}{l}\text { A large number of competitors and their } \\
\text { approximate equality }\end{array}$ & \multirow{5}{*}{$\begin{array}{l}\text { Price competition } \\
\text { Advance complex application } \\
\text { Improvement of goods and services quality } \\
\text { Differentiation of goods and services }\end{array}$} \\
\hline & & Slow growth of a market segment aggravating fight & \\
\hline & & Sale of the same goods and services & \\
\hline & & The output increases rather fast rates & \\
\hline & & Exit barriers from the market are high & \\
\hline 1 & 2 & 3 & 4 \\
\hline 6 & Innovations & New or advanced goods release by competitors & $\begin{array}{l}\text { New strategy elaboration Mutually advantageous, } \\
\text { partnership with suppliers and consumers } \\
\text { Strategic and adapting innovations application, including } \\
\text { methodological device of innovative logistics }\end{array}$ \\
\hline
\end{tabular}

As we can see from the table, the potential of a certain market segment will depend on influence power of suppliers, consumers, existing and potential competitors, goods substitutes and innovations, and also on barriers to enter the market. Strengthening market position can be expressed in establishment of mutually beneficial relations with suppliers and consumers, differentiations of goods and services due to advance complex application, and also by means of latest developments use in the sphere of management, equipment and technology at goods production and rendering services. Innovations classification is e, but within this work we take into consideration management innovations. Thus, allocating innovations as an independent competitive market force, we should note that logistics possesses an innovative potential in the management sphere, capable to increase efficiency of market subjects managing. So the main reference point in logistics is quality of ultimate consumers service.

\section{Conclusion}

Logistic system efficiency of competitive strategy is defined by protection efficiency against competitive forces influence, compensation possibility of competitive pressure and ability to create steady competitive advantages.

The understanding of competitive pressure basic factors will provide a strong base for a strategic action plan which can be presented as follows:

1) logistic system positioning to ensure protection against competitive forces influence;

2) influence on competitive forces arrangement due to strategic maneuvers to strengthen a company position on the market;

3) forecast of determining competitive forces factors, timely response to them at the expense of a strategy choice.

To make a logistic system balance strategic and operational opportunities, it has to take into account an external and internal situation and correct its position to achieve desirable results. Such approach leads to that fact that company environment analysis and interpretation are a key factor of its strategic success.

So, the main goal is market position defining when strategy is developed where the company will be protected from competitive forces influence or will be able to have impact on them.

\section{References}

Aaker. Strategic market management. 7th edition. / Translation into English under the editorship of S. G. Bozhuk. - St. Petersburg, 2007. - 496 pages - (Management Theory).

Ansoff, I. Strategic management. Classical edition. - SPb.: St. Petersburg, 2009. - 344 pages.

Бауэрсокс, D. D. Logistics: integrated delivery chain I D. D. Baueroks, D. D. Klos. - Moscow: Olympus - Business, 2008. -640 pages

Dybskaya, V. V. Logistics: integration and optimization of logistic business processes in delivery chains / V. V. Dybskaya, E.I. Zaytsev, 
V. I. Sergeyev. - Moscow: Eksmo, 2009. - 944 pages - (Full course of MBA).

Ilyina T.A. Organizational and economic mechanism of university innovative activity stimulation: dissertation, candidate of Economics. Samara, 2006. Pages 10-17.

Kaplan, R. S. Balanced indicators system. From strategy to action / R. S. Kaplan, D.P. Norton. - 2nd edition, corrected and added Moscow: Joint stock company the Olympus - Business, 2006. - 320 pages.

Kaplan R. S., Norton D.P. Strategic unity: creation of organization synergy by means of balanced indicators system. - M.: Production. house "Williams", 2006. - 384s.

Kurbatov O., Novikov D., Novikov F. Basic and innovative logistics as two parts of uniform science and sphere of action//RISK. 2007. No. 2. - Page 64.

Kurbatov O. N., Protsenko I.O., Novikov F.D. Conditions of innovative logistics use in various spheres of public work//RISK. 2007. - No. 4. - Pages 56-60.

Linders M.R., Fearon H.E. Management of supply and stocks. The logistics / Lane with English - St. Petersburg.: JSC Viktoriya plus, 2006. -768 pages.

Models and methods of logistics theory : 2nd edition. / Under the editorship of V. S. Lukinsky. - St. Petersburg, 2007. - 448 pages.

Mintsberg G., Alstrend B., Lempel Dzh. Schools of strategy. St. Petersburg, 2001. - 478 pages.

Novikov, D. T. Use of innovative logistics in hospitality industry: I D. T. Novikov, V. I. Stepanov, Russian Economic Academy of G. V. Plekhanov. - Moscow: Publishing house of REA of G. V. Plekhanov, 2009. - 75 pages.

Novikov, D., Krichmar M. Innovative logistics in tourism//RISK, No. 3, 2006 - page 30-31

Novikov D. A. Theory of organizational systems management, Moscow: MPSI, 2005. - 584 pages.

Novikov D., Grebnev E., Horn And. Control relations systems with clients (CRM) and their advantages//Environments of commodity markets: marketing and logistics, №. 1, 2007 - page 47-52

Porter M. E. Competition, translated from English, Moscow, 2005. - Page 45.

Savitskaya G. V. Analysis of enterprise economic activity. - 5th edition, Moscow, 2009. - Page 369.

Stock J. R., Lambert D. M. Strategic logistics management. - Moscow: INFRA-M, 2005. - 830 pages.

Thompson - Artur A., Striklend III, A. J. Strategic management: concepts and situations for the analysis, the 12th edition: Translated from English - Moscow: Williams publishing house, 2006. - 928 pages: silt.

Waters, D. Logistics. Management of delivery chain: Translated from English - Moscow: UNITY-DANA, 2003. - 503s.

Faye L., Rendell R. MBA course on strategic management: translated from English Moscow, 2002.

Fatkhutdinov R. A. Innovative management. St. Petersburg, 2008. - Page 16.

Porter M. E., Elizabeth Olmsted Teisberg E. O. Redefining Health Care: Creating Value-Based Competition on Results. - Boston: Harvard Business School Press, 2006. - $506 \mathrm{p}$. 